\title{
Threats to wild buffalo (Bubalus bubalis arnee): A case of Koshi Tappu Wildlife Reserve
}

\author{
Ila Yadav* and Ramesh Prasad Sapkota \\ Central Department of Environmental Science \\ Tribhuvan University, Kirtipur, Kathmandu, Nepal \\ *E-mail: ila_yadav2002@yahoo.com
}

\begin{abstract}
Bubalus bubalis arnee is an endangered species and is among one of the protected animals in Nepal. The present study was undertaken to identify the threats to wild buffaloes, to study their habitat and people perception towards them. To know the perception of the local people towards wild buffalo questionnaire survey was carried out in 5 adjoining eastern VDCs of Sunsari district of Koshi Tappu Wildlife Reserve. The major reason for conflict between local people and reserve were crop damage, human causalities and no proper compensation for their losses. Major conservation threats of wild water buffaloes were, in-breeding and cross-breeding, illegal collection of natural resources from the reserve, competition with domestic buffaloes for resource inside the reserve, park people conflict and flooding.
\end{abstract}

Keywords: Competition, crop damage, in-breeding, management, park people conflict

\section{Introduction}

The country Nepal is small in size, covering $0.1 \%$ of the total land surface of the earth (Shrestha, 1991), is very rich in its biological diversity. But it is matter of worry to see that habitat destruction, population pressure and food shortages are exerting tremendous pressure on the ecosystems of Nepal (Kherwar, 1996). Bubalis bubalis arnee which is a member of the bovinae subfamily and the ancestor of all the abundant domestic water buffalo varieties can be a good example for it. The World Conservation Union, Red List of threatened species classifies "Wild Water Buffalo" (Bubalus bubalis arnee) as an endangered species. This endangered species is also one of the protected mammals in Nepal included in appendix CITES III. There is great concern about the viability of the wild buffalo in KTWR. (Sah, 1993; 1997). In this regard, the present study tried to explore the threats to the wild buffalo population, attitude of local people toward it and the vegetation composition of its habitat.

\section{Materials and Methods}

\section{Study area}

The KTWR extends from $86^{0} 55^{\prime} 15^{\prime \prime}-87^{0} 05^{\prime} 02$ "E longitude and $26^{0} 333^{\prime} 57^{\prime \prime}-26^{0} 43^{\prime} 49^{\prime \prime} \mathrm{N}$ latitude (Fig. 1). It lies in the alluvial flood plains of the Saptakoshi river bordering Saptari, Sunsari and Udaypur districts of eastern Nepal. KTWR was gazetted in July 1976 primarily for the protection of wild buffalo. It covers a total core area of $175 \mathrm{sq} . \mathrm{km}$.

\section{Data collection}

Both primary and secondary data were collected to assess the threat and habitat of wild buffalo in KTWR. Primary data collection was done directly from field through direct and indirect observation of wild buffalo. The potential area was surveyed by the evidences as droppings, exudation of sap, crushed tissues, fresh clipping, direct sighting during the active periods of dawn and dusk. 


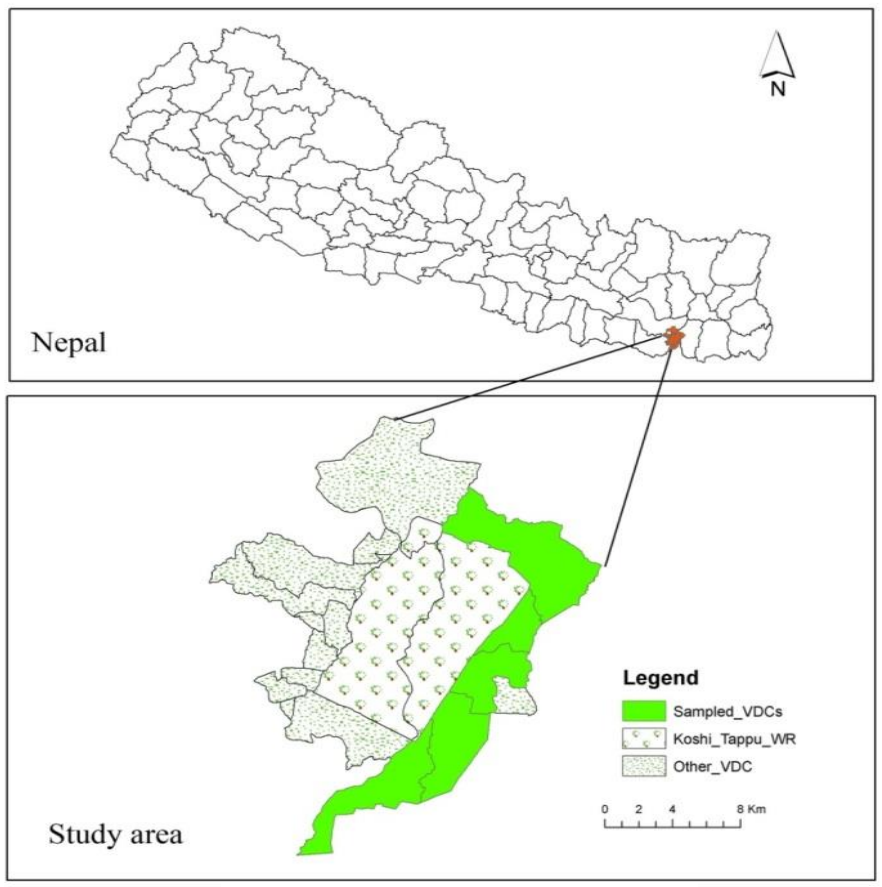

Figure 1. Map of the study

Vegetation analysis

21 quadrats each of area $25 \mathrm{~m}$ X $25 \mathrm{~m}$ for trees; 42 nested quadrats of $10 \mathrm{mx} 10 \mathrm{~m}$ for shrubs and 84 quadrats of $1 \mathrm{~m} \times 1 \mathrm{~m}$ for herbs were laid. $1 \mathrm{~m} \times 1 \mathrm{~m}$ quadrats were laid down in four corners of the each $25 \mathrm{~m}$ X $25 \mathrm{~m}$ quadrats. Within each quadrat of each of $25 \mathrm{mx} 25 \mathrm{~m}$ plot, all the trees were counted, their DBH were measured using diameter tape and their heights were measured using clinometer. Species composition and percentage cover of shrubs and herbs and their respective frequency were recorded. The different type plants found in the site was identified and listed.

\section{Threat assessments}

Disturbances in habitat were assessed through the direct observation and through interviews with the local people and reserve authorities in the area. Alternatively, number of livestock dung as well as direct livestock grazing encountered in the quadrates was counted to make an index of livestock pressure in the area. The herders and the local people were interviewed regarding the livestock number and weekly duration spent in the area. Grazing intensity (Table 1) was determined, by using the formula,

Grazing intensity $=$ Livestock number $\mathrm{X}$ Weekly duration spent

Cattle dung density/ha $=$ Total number of cattle dung encountered X 10000/ Number of quadrats X Area of a quadrat (Ahlborn and Jackson, 1987).

\section{Attitudinal survey}

For the attitudinal survey, five VDC were selected, Madhuwan, Prakashpur, Paschim Kushaha, Haripur and Shreepur. Questionnaire survey was conducted on the eastern side of the reserve. A structured and open- end questionnaire was prepared for this purpose. From each VDC 80 local 
people were randomly selected for the survey. Altogether, from five VDC, 400 local people were sampled. Questionnaire survey directly assesses the attitude towards wild buffalo and reserve. The questionnaire survey was conducted in April, 2013.

Table 1. Grazing intensity categories

\begin{tabular}{cll}
\hline Categories & Grazing intensity & Relative use \\
\hline 1 & $0-249$ & Light \\
2 & $250-499$ & Light \\
3 & $500-999$ & Light \\
4 & $1000-1999$ & Moderate \\
5 & $2000-3999$ & Moderate \\
6 & $4000-5999$ & Moderate \\
7 & $6000-7999$ & Heavy \\
8 & $>8000$ & Heavy \\
\hline
\end{tabular}

\section{Results and Discussion}

\section{Habitat analysis}

Density, frequency, coverage and IVI of the species were calculated from the sampling sites. 50 herbs were found in the sampled sites. Among 50 species of herbs, Imperata cylindrica shared the highest density and the most frequent species that covered the most of the portions of the wild buffalo habitats. It also shared the highest coverage and highest IVI . The most dominants herb was Imperata cylindrica followed by Saccharum spontaneum, Phragmites karka and Cynodon dactylon.

Total 9 species of shrubs were found in the habitat of wild buffalo sites. Mimosa pudica possessed the highest IVI among them. Its density and frequency were also highest among the 9 shrub species found. The highest coverage was of Chromoleana odorata. The dominant shrubs were Mimosa pudica, Chromoleana odorata and Lantana camera.

Altogether 9 species of trees were found. Out of 9 tree species, Acacia catechu had the highest IVI. Density, frequency and basal area of Acacia catechu was also highest among the tree species followed by Dalbergia sisoo and Bombax ceiba

\section{Threats assessment}

Cross-breeding of domestic and wild buffaloes: One of the major threats for conserving the pure wild buffalo breed is cross-breeding with domestic buffaloes and in-breeding with wild buffaloes. With the increase in human population there number of livestock is also increasing in the reserve. The small size of the reserve, seasonal inundation and higher number of livestock inside the reserve is leading to problems of in-breeding of wild buffalo at one hand and crossbreeding with the domestic buffalo other hand.

Grazing: It is one of the main threats for the conservation of wild buffalo. Livestock farming is a traditional mode of subsistence for many people in buffer zone. There are less public lands left outside for grazing, so there is no alternative to use the reserve as a land for grazing and bringing their livestock into the reserve for sharing food with the wild animals. In the survey of grazing intensity, most of the herd was composed of minimum of 40 and maximum of 150 cattle and 80-85 herds of cattle was found in most of the area. Their average weekly duration spent in the reserve was 84 hours that might change according to the availability of the fodder in the area. Hence according to relation used by Ahlborn and Jackson (1987), grazing intensity in 
the study area was found to be 6720 which is very high. Due to higher number of livestock inside the reserve, cattle dung density in the habitat of wild buffalo was found 176/ha in the sampled sites. Higher the cattle dung density, higher is the livestock pressure.

Utilization of the forest resources: Local people heavily depend upon the forest resources of the reserve. They enter the reserve illegally to collect timber, fuel wood, fodder and grass. The reserve forest and driftwood collected from the Koshi flood are the major sources of fuel wood for the local people. Legal grass cutting, which involves thousands local people is permitted round the year. The food preferred by the wild buffalo such as Imperata cylindrica, Saccharum sponteneum, Typha elephata, Cynodon dactylon are used by the local people for fodder to livestock, making mat, brooms, basket and for firewood purposes. The other major plant species found in the habitat of wild buffalo such as Ipomea, Typha, Mimosa pudica, Eupatorium adenophorum are used for medicinal value and for food. The needs of the local people and the wild buffalo are fulfilled from the same place.

Flood and river erosion: Flooding is also one of the main threats to the wild buffaloes in KTWR. There are high chances of sweeping the wild buffalo especially the calves. Most of the area gets inundated in flood causes food and space shortage. Inundation of land for long time sometimes leads to death of wild buffalo. Along with the flood the position changing course of Koshi river not only erodes the land of reserve but also destroys forests, wetlands and even wildlife. The flood of year 2008 has caused meandering of the Koshi river and also loss of wildlife, grassland and habitat of wild animals.

Diseases and parasites: The threat of disease to wildlife in Nepal is a largely un-quantified factor for many species. However due to close association dietary and habitat overlap of many wild and domestic animal, the risk of transmission of disease such as tuberculosis, foot-andmouth disease is high. Disease epidemics spreading from domestic livestock presumably pose a threat, especially where there is close overlap of wild buffalo populations and domestic livestock, the high density especially of latter, and the small and localized nature of wild buffalo populations. In KTWR, the wild buffalo have to share its food, space with domestic buffalo; they live together in some herd which creates greater chances of transmission of diseases.

Invasion of weeds: Species of weeds such as Chromoleana odorata, Eupatorium adenophorum, Lantana camera, Mikania micrantha are invading the forest areas and grasslands of the reserve which is leading to loss of food and destruction of habitat. The invasive Mikania species potentially threatens wetlands in South Asian range of wild buffalo (Aryal, 2011). In the present study of vegetation analysis of habitat of wild buffalo, it was found the invasive species Lantana camera covers the third highest IVI and Chromoleana odorata showed the highest coverage among shrubs in the sampled sites.

Hunting and poaching: Poaching remains a significant threat to many species. The hunting of wild animals including wild buffalo has been common practice to people prior to the declaration of the area as a reserve. Still some people are involved in poaching and hunting. A primary reason for poaching is for subsistence due to poor socio-economic condition of the people living in the buffer zone and inadequate alternative livelihood opportunity. Generally the hunting of the wild buffalo in KTWR is done for their meat and hides. The selling of the skull is also considered threat to few remaining population in Southeast Asia.

Road-traffic accidents: Since the east-west highway being located adjacent to the reserve, wild buffaloes are threatened by heavy vehicular accidents, especially during night.

Forest fire: Every year during the dry season the forest area is put to fire by local people. During this period, there is shortage of food for wild buffalo. They have to compete with other wild 
animals and livestock for food. Fire not only burns grass but also destroys seedlings, demises soil quality and also help in growth of unwanted plant species. Fire cause to reduce the productivity of soil and is vulnerable to erosion.

Habitat loss/ degradation: Local people use the forest resources to meet their day to day needs. Land encroachment by local people, livestock grazing inside the reserve, flood and constructional activities inside the reserve is leading to habitat degradation of wild buffalo in KTWR. The habitat of wild buffalo faces intensive encroachment from livestock and human as well.

Land encroachment: The encroachment of the land in reserve is increasing at present. The major causes of land encroachment include unclear boundaries, growing population, and migration of people from other places.

Poisoning: Local farmers use different insecticides and herbicides on wheat, paddy and other crops to protect them from insects. Since the wild buffaloes frequently visit the agricultural lands, they have greater chances of being the victims of these practices. During the field study it was observed that many people are also involved in illegal fishing. For fishing occasionally DDT powder, insecticides are used to kill the fishes. Such activity pollutes water. These activities indirectly affect the wild buffalo.

Park-people conflict: Conflict between people and wildlife is a major conservation issue that is difficult to resolve (Heinen \& Kandel, 2006a,b). Crop damage, human injury and casualty mainly by the wild buffalo are major causes of resentment towards the establishment of the reserve. Crop damage by wild buffalo has adversely affected the economy of local people. They do not get proper compensation for the damage due to which they look wild buffalo as a problem creater. People have been denied the right to free utilization of the resources inside the reserve due to which they have built negative attitude towards the reserve. Situation is escalated often by human fear and frequently results in the injury or fatality on both sides.

Poor management of the reserve: Different rules and regulations regarding the management of the reserve are made but they are not seen strictly implemented. Different wild buffalo habitat disturbing activities such as several herds of domestic buffalo, local people involved in extracting the resource of the reserve without the permission of the reserve authority and broken electric fences are seen at different places.

Attitude towards wild buffaloes: $62 \%$ of the sampled population in all five VDC displayed positive attitude towards the reserve. The reason behind this might be due to the direct and indirect benefits that they are getting from the reserve and 38\% showed negative attitude towards the reserve the main reason behind it was harassment due to wild buffalo such as crop depredation, human causalities and not getting compensation for their losses, restriction on use of resources and weak management, which were also the main reason for conflict between reserve authorities and the local people.

On surveying the main reason behind the negative attitude towards the reserve, the reasons were, crop damage due to wild water buffalo in which $66 \%$ agreed, $28 \%$ said not getting proper compensation for the losses done by wild buffalo and rest $6 \%$ said for restriction of not allowing to use the resources freely (Figs. 2-8). 


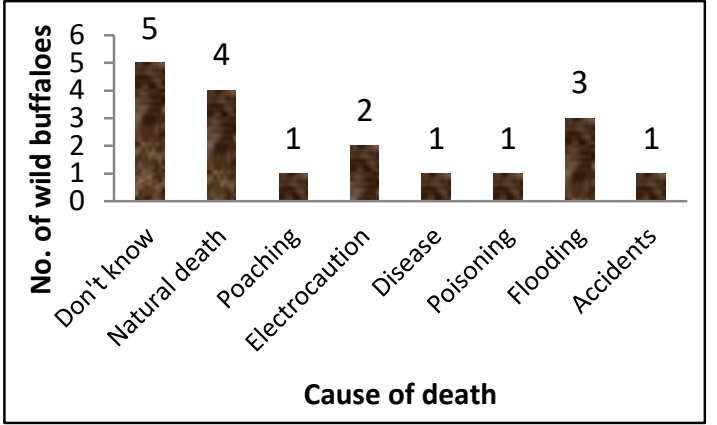

Figure 2. Cause and death of wild buffalo in KTWR (2006-2014).

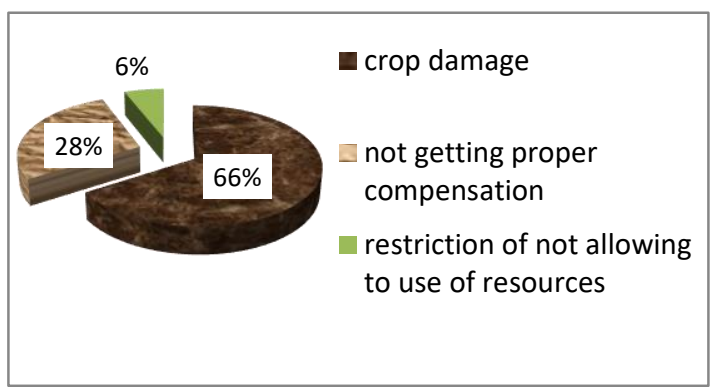

Figure 4. Main reason of conflict between local Figure 5. Problem faced due to wild buffalo people and reserve

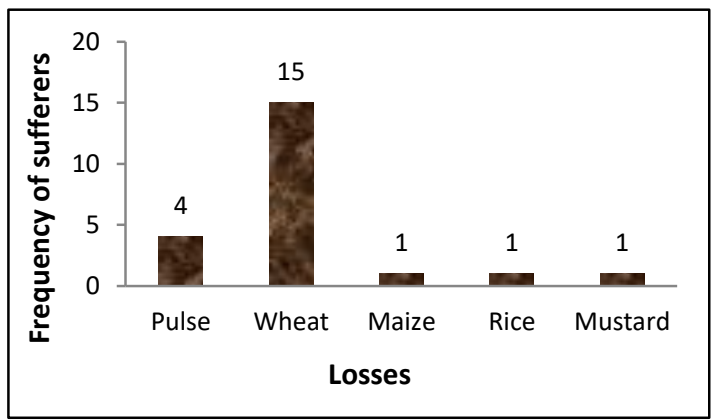

Figure 6. Agricultural losses due to wild buffalo (2011-2014).

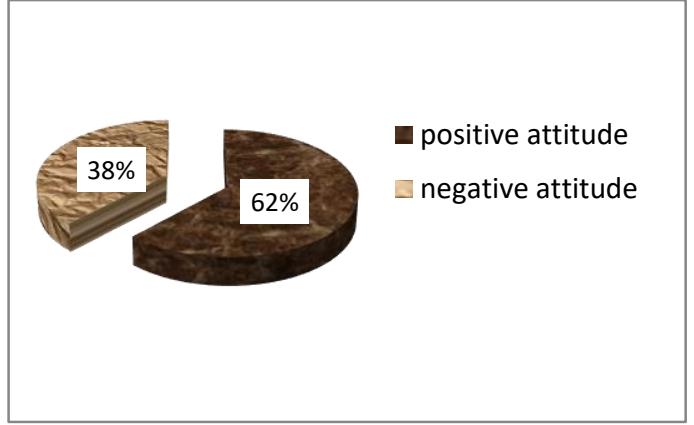

Figure 3. Attitude of local people towards the reserve
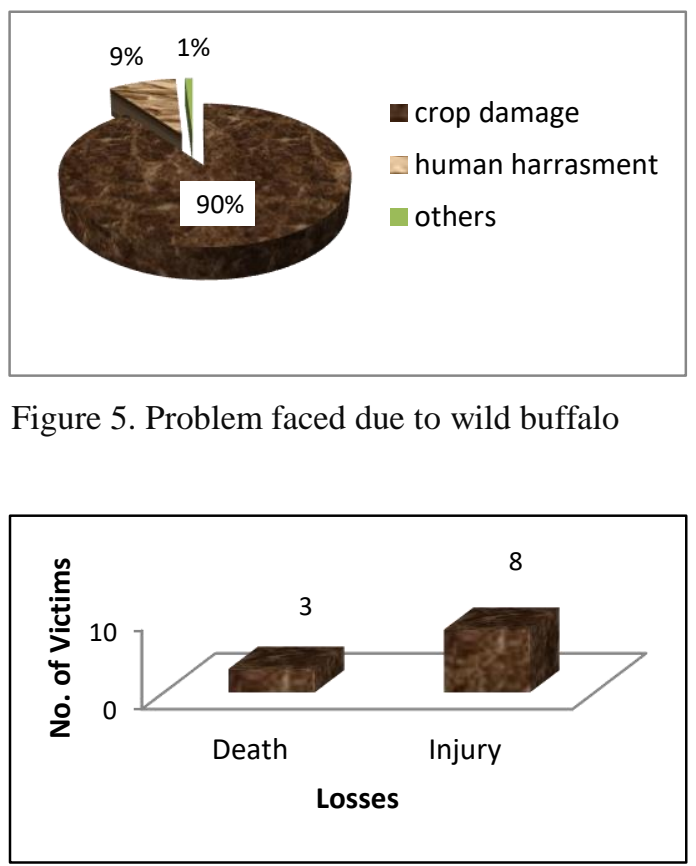

Figure 7. Victims of wild buffalo in 5 sampled VDCs (2011-2015).

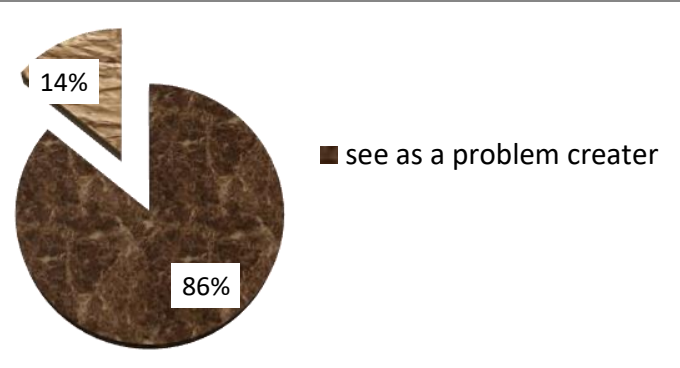

Figure 8. Percentage of population who see wild buffalo as problem creater. 
On asking the major problem they face due to wild buffalo, $90 \%$ said crop damage, $9 \%$ human harassment and remaining $1 \%$ said other reasons. The major loss due to wild buffalo was agricultural loss; majority was on wheat followed by pulse. Beside that the human attack by wild buffalo was also found in the area.

Inspite of knowing the importance of wild buffalo they said they see wild buffalo as a problem creater because wild buffalo is the main cause of the crop damage and harassment. The result for this is, $86 \%$ respondent said they see wild buffalo as problem and 14\% said that they don't see wild buffalo as problem.

On asking the alternatives to the problems created by wild buffalo, 55\% respondent supported for compensation for their losses, $25 \%$ for fencing the reserve followed by $15 \%$ shifting wild buffalo and $5 \%$ for shifting people.

\section{Conclusions}

Among herbs, shrubs and trees found in the habitat of wild buffalo, Imperata cylindrica, Mimosa pudica and Dalbergia sisoo were the dominant respectively. Even though the numbers of wild buffalo have been increased but there are several threats to its population. The small size of the reserve, seasonal inundation and high grazing pressure is leading to problems of eroding the pure wild gene pool of the last remaining of wild buffalo. Grazing has caused competition for food, habitat shrinkage of wild buffaloes. Human activities such as fishing, stream poisoning, using of pesticides and insecticides might show its impact in future because the wild buffaloes make use of the water and graze on the grassland. The meandering of Koshi River and seasonal flood is also threat to wild buffalo population. People of villages are victims of wild buffalos since it cause crop damage and other harassments. People on their part, kill or harm it. Even people are aware of importance of wild buffalo. Due to weak management policy, KTWR area is heading towards its doom. The reserve which is mainly preserved to support the last surviving population of wild buffaloes does not seem secured there. The negative interface that now exists between the wildlife reserve and the people is causing heavy loss on the both sides. The physical nature of the reserve does not include the full annul home range of wild buffalo.

\section{References}

Ahlborn, G. \& Jackson, R. 1987. A survey of Sagarmatha National Park for the endangered snow leopard. Department of National Parks and Wildlife Conservation, Kathmandu, Nepal

Aryal, A. 2011. Call to conserve the wild water buffalo (Bubalus arnee) in Nepal, Internation Journal of Conservation Science, 2(4): 261-268.

Heinen J.T. \& R.C. Kandel. 2006a. Arna/ Wild Buffalo count-2004. Koshi Tappu Wildlife Reserve, Nepal.

Heinen, J.T \& R.C. Kandel. 2006b. Threats to a small population: a census and conservation recommendations for wild buffalo (Bubalus arnee) in Nepal. Oryx 40: 324-330. http://dx.doi.org/10.1017/S0030605306000755

Kherwar, P.K. 1996. Endangered Environment of Wild Buffalo of Koshi Tappu with Reference to Anthropological Impacts. M.Sc. Thesis, Central Department of Zoology. Tribhuvan University, Kirtipur Kathmandu, Nepal.

Sah, J.P. 1993. Wetland Vegetation and its Management: A Case Study in Koshi Tappu Region, Nepal. M.Sc, Thesis INRDM program, Asian Institute of Technology, Bangkok, Thailand.

Sah, J.P. 1997. Koshi Wetlands: Nepal's RAMSAR SITE. IUCN Nepal. pp. 254.

Shrestha, J. 1991. Biodiversity of Koshi Tappu Wildlife Reserve and its Adjacent Area. Woodland Mountain Institute and IUCN, Nepal in Collaboration with DNPWC/ Nepal, and ORAIN, Denmark, Kathmandu. 